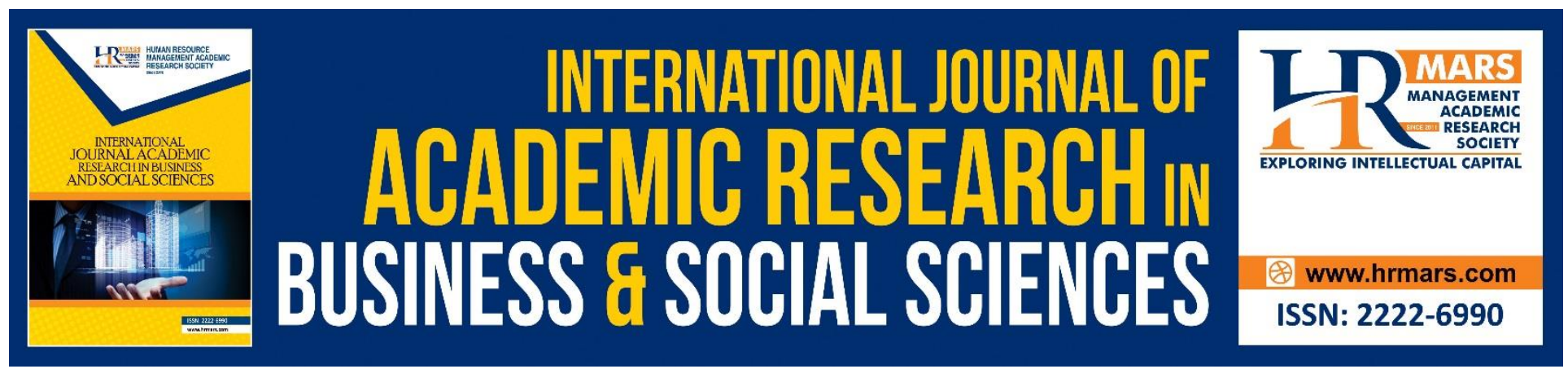

\title{
Analysis of Firms' Characteristics Affecting the Sustainability Reporting Disclosure in Malaysia
}

\author{
Nazaria Md. Aris, Suzila Mohamed Yusof, Nur 'Izzah Imani Idris, Nurul \\ Syuhada Zaidi, Razman Anuar
}

To Link this Article: http://dx.doi.org/10.6007/IJARBSS/v11-i14/8325

DOI:10.6007/IJARBSS/v11-i14/8325

Received: 16 November 2020, Revised: 03 December 2020, Accepted: 29 December 2020

Published Online: 20 January 2021

In-Text Citation: (Aris et al., 2021)

To Cite this Article: Aris, N. M., Yusof, S. M., Idris, N. I. I., Zaidi, N. S., \& Anuar, R. (2021). Analysis of Firms' Characteristics Affecting the Sustainability Reporting Disclosure in Malaysia. International Journal of Academic Research in Busines and Social Sciences. 11(14), 1-20.

Copyright: (c) 2021 The Author(s)

Published by Human Resource Management Academic Research Society (www.hrmars.com)

This article is published under the Creative Commons Attribution (CC BY 4.0) license. Anyone may reproduce, distribute, translate and create derivative works of this article (for both commercial and non-commercial purposes), subject to full attribution to the original publication and authors. The full terms of this license may be seen

at: http://creativecommons.org/licences/by/4.0/legalcode

Special Issue: Contemporary Business and Humanities Landscape Towards Sustainability, 2021, Pg. 1 - 20 http://hrmars.com/index.php/pages/detail/IJARBSS

Full Terms \& Conditions of access and use can be found at http://hrmars.com/index.php/pages/detail/publication-ethics 


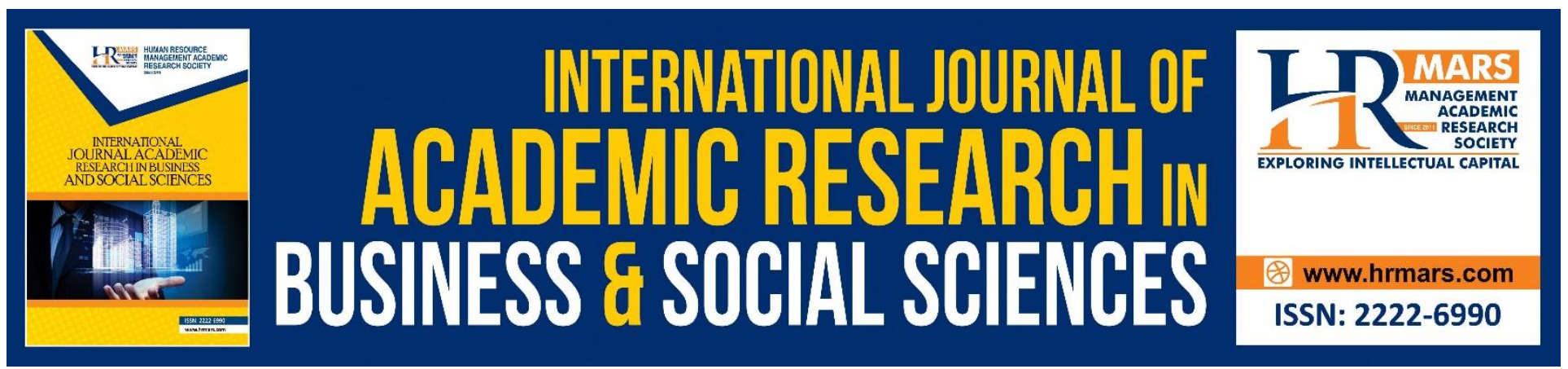

\title{
Analysis of Firms' Characteristics Affecting the Sustainability Reporting Disclosure in Malaysia
}

\author{
Nazaria Md. Aris, Suzila Mohamed Yusof, Nur 'Izzah Imani Idris, \\ Nurul Syuhada Zaidi, Razman Anuar \\ Faculty of Economics and Business. Universiti Malaysia Sarawak, Kota Samarahan, Sarawak \\ Email: manazaria@unimas.my
}

\begin{abstract}
s
In today's dynamic and challenging business environment, the numbers in company's financial statements alone do not represent full information on company's overall performance demanded by various parties. Behind the numbers, companies are obliged to report on the economic, environment, social and governance factors that impact their business daily activities. Thus, companies embed sustainability reporting in response in taking the economic, social and environmental performance into account. This paper concerns to analyse the effect of firm characteristics' proxied by firms size (FSZ), firms type (FTY) profitability (PRO), and achievements $(A C H)$ towards sustainability reporting disclose (SRD). The control variable in this study is internal goals (ING) of the company. There are four types of theories that are related with this study, which are institutional theory, legitimacy theory, stakeholder theory and agency theory. Of the data collected from 60 companies' annual report in Bursa Malaysia for three years from 2014 to 2016, the results revealed that company's size, profitability and achievements have significant relationship with sustainability reporting disclosure. This study is important study to companies in Malaysia to sustain their business and competitiveness over the long term in order to attract the investors. This study contributes insight for managers to improve on the disclosure of material narrative statement in their annual reports. Not only this study benefits companies and managers but also to investors as they are interested to understand how organisations correspond to the risks and opportunities of non-financial matters such as economic, environment, social and governance.
\end{abstract}

Keywords: Sustainability Reporting Disclosure, Firms Size, Firms Type, Profitability, Achievements

\section{Introduction}

One of the areas of accounting research that is still a rising prominence in the world is Sustainability Reporting (SR). According to the Global Reporting Initiative (GRI), SR is defined as a company report that summarizes the information of economics, environmental, social and governance efficiency in the company's day to day activities. SR is a new thing that evolve in Malaysia and that explains why 
most of the companies listed in Bursa Malaysia are still using Corporate Social Responsibility (CSR) reporting to report on their corporate social responsibility actions and results (Zain, 1999; Haniffa \& Cooke, 2002; Amran \& Devi, 2008).

Hence, SR functioned as a key of operating system for the company in communicating the sustainability performance and the impacts of the performance towards company regardless of the positive or negative outcomes it produced (Amran, 2010). There are numerous standards available for measuring sustainability practices among organizations. For example, the Dow Jones Sustainability Index, the ISO 14000 series, the social accountability 8000 standards and the Global Reporting Initiatives (GRI) (Zahid et. al, 2016). Malaysia is one of the worldwide countries which progressively moving towards in achieving the sustainability development. Sustainability development influenced Malaysia to use it by "International community has growing the Malaysia diplomatic impress and the protest of wanton deforestation voice" (Hezri and Hasan, 2006). Moreover, "The concept is developed to the general public by a wave of media engrossment towards sustainable development" also influenced Malaysia to develop sustainably (Hezri and Hasan, 2006, p. 43). According to Corina Joseph (2010), there is an issue of the sustainability which received substantive captious engrossment in Malaysia. The scope starts with the government and then passes to society, the media and the non-governmental organizations (NGOs). Bursa Malaysia has shown commitment to SR as it needs the companies listed to disclose a narrative of their economic, environmental and social (EES) risks and opportunities in the company's annual report. Bursa Malaysia suggested that the company must focus on the materiality, governance and management of the company encouraging the company to bring together investor relations and sustainability teams and agree on how sustainability supports the investment proposal which can be concluded as the main advantage for the company to succeed in the business. The reason is because, compliance with the initiative will take significant thought, internal alignment and potential changes in organization although most of the companies think that initiative is easy for them. Based on Baden and Harwood (2013), sustainability has been established with the related terms consisting of sustainability, ethical footprint, ecological rucksack, triple bottom line, CSR, corporate social performance (CSP), corporate social responsibility, moral muteness, responsible entrepreneurship and several others. At the end of the decade, the first SR was developed in the mid-1990s in a corporation with the emplace of GRI SR guidelines in 1999. GRI applies to SRs, such as the trial for measurement, transparency and accountability test for internal and external stakeholders of companies. This purpose is to handle and counterpoise their productive work with the environment and surrounding communities (Poolthong and Mandhachitara, 2009)

In Malaysia, the companies did not influence with the existence of sustainability reporting since this reporting is voluntary reporting. In year 2005, Bursa Malaysia started to implement the guideline of this reporting and attracted the companies to use SR in their business operation. The topic of SR is a new issue, has been debated and starting to get concerned from various parties. The benefits from SR are the factors that drive SR investment has been examined through the Global Reporting Initiative (GRI). These benefits can be classified into internal and external benefits. Internally, SR is important because it can integrate and balance the performance of a business. This is because companies must arrange strategies to perform well in the business. Besides that, this study intends to evaluate what determinants drive companies to use SR in their respective businesses. To make sure that the 
suppliers of the companies meet a certain level of sustainability, reporting is now an effective tool for businesses, as the number of companies inquired their suppliers to report in detail on economics, social and governance (ESG) issues had increased. Based on the Director of the GRI's Focal Point USA, Mike Wallace, he provided examples such as Microsoft and Apple, which asked their supplier for comprehensive details because they did not generate a sustainability report. Although the number of companies that used reporting which is including the CSR reporting, many other companies still did not know how to use or material of the report. John Buckley, Managing Director and Head of CSR at BNY Mellon, points out that the GRI report is a box checking effort because it is a valuable exercise but does not relate to the core of the company's efforts. He also said that by giving a great report through GRI, it does not make the company as a great company.

Next issue is framework or guideline that has been used by the companies in the SR. Companies can apply different approaches of sustainability report not just depending on the GRI guideline because the values of the performance can be find more in any other ways. Most of the companies in Malaysia used CSR as the report rather than using SR alone because it is still new in Malaysia and there is no requirements or standards that should be followed by listed companies in the CSR report to disclose information based on that standards. Bursa Malaysia, the stock exchange in Malaysia never sets which information should be disclosed for listed companies.

\section{Literature Review and Hypothesis}

\section{Theoretical framework}

The results from previous studies and have shown that sustainability reporting became crucially important, requiring businesses to reflect on the following actions: realizing a vision for the future, presenting logically the issues emerging from the sustainability study as part of the company's annual report; evaluating the unique challenges faced by the organisation in improving the process of moving to corporate Sustainability Reporting, by reducing the current financial performance gaps; and formulating specific policies to ensure that financial reporting is enforced, tracked and transparent in relation to the experience and practise set out in the social and political context of reference (Gus et.al,2016; Hategen et. Al, 2018; Izzo et. Al, 2020 and Munteanu et. Al, 2020). Therefore, there are four types of theories were adopted in this research, namely institutional theory, legitimacy theory, stakeholder theory and agency theory. First, institutional theory is a wide concept which is has many elements involved since the theory evolved in the early twentieth century. Based on Selznick, $(1449,1996)$, comparison between the old institutionalism and the new institutionalism to explain the differences to advance the notion of institutional theory that enable to strain all the categorize and meanings implanted in both concepts. The main dissimilarity between old institutionalism and new institutionalism is the institution's view of researchers including DiMaggio and Powell (1991), which matches isomorphism and Selznick (1996) on the canon of power, subordination and responsibility. Besides that, academics have taken into account the differing form of institutional theory used by the new institutional sociology to explain organizational change (Modell, 2001, 2005, 2005), (Tsameyi et al, 2006). Then, Brignall and Modell (2000) took the view that institutional theory could explore organizational change by incorporating benefits and power from various stakeholders, while Thornton and Ocasio (2008) competed that institutional logic provides a connection between certain previous institutional theories. Second, Suchman (1995) defined the theory of legitimacy as an overall view or assumption which is desirable, appropriate or applicable to 
an entity.All of the engagement need to have some norms, values, beliefs, and meaning that publicly created while Crosman, (2013) defined legitimation as a progression of a community system or characteristic to be perceived as applicable. According to the Deegan and Unerman, (2011), legitimacy theory depends on the notion which there is a "social contract" between a company and the society in its operations. Besides that, Deegan, (2002) also explained the social contract as a lot of expectations which society has about the way of a company conducts its operations. Deegan, (2002); Deegan \& Blomquist, (2006); O’Donovan, (2002) point out that legitimacy theory can estimates the companies which are embrace the environmental and social responsibility reporting. This is to legitimize the operation of the companies when changes in the norms and expectations of the business entities in society have occurred or when companies are faced with violations of the present norms and expectations of society. Based on the Maignan and Ralston, (2002), corporate legitimacy refers to the maintenance of complementary relations with its stakeholders. Third, stakeholder theory implies to identify the groups to whom a company should be responsible. Stakeholder theory defined by Freeman, (2010) as "a theory of the administrative that controlling and commercial ethics that stresses about ethics and standards of method in handling a company". Freeman (1984) clarified that company should consider comparing the claims of all other stakeholders who may impact or be influenced by the achievement of the company's objectives. This theory involves the need for corporations to play an active role in society. The reason is companies need to look at the factors through their actions on the theory of stakeholders highlighting the importance of all parties included entity that directly or indirectly affected the operations of the company (Wicks et. al, 2004). Boatright (2003) defines the company as being operated for the good of all individuals interested in the business, such as shareholders investing their money in the company while workers invest their time and intellectual resources in the company, customers invest their confidence with the company through business and provide the company with the infrastructure and education for future employees for the communities (Graves et al.,2001). Hence, can be conclude that any group that chooses to contribute to the organization may have the right as stakeholders, including staff, clients, vendors, stockholders, banks and government and all stakeholders, to know the social and environmental consequences of the business on a daily basis (Deegan, 2013). Lastly, the definition of agency theory is explained by Jensen and Meckling (1979) as a contract under principals that occupy the agent to commit services for their behalf that include in representative for decision making authority for the agent which is agent represent the managers of the company while for principles are refer to the shareholders of the company. This theory looks upon the people are rational in the market which is refer to the managers, shareholders, creditors, experts, governments and other players in the market act to wisely thinking when making decision which rise their welfare. Besides that, managers need to be opportunistic to raises agency cost for the companies. To reduce the agency cost from the development of information asymmetry, voluntary disclosure can be used by the company. Through the disclosure information, the shareholders can keep an eye on the managers through monitoring and adherence activities. Serafeim et al (2011) explained that companies will raise more flexibility to financial resources when the companies have commitment to bear the social responsibility such as raised the companies' investment activities to increase wealth and increase the companies' market value to rise the share price. SR disclosure is an effective way to reduce the cost of the agency or information asymmetry 
INTERNATIONAL JOURNAL OF ACADEMIC RESEARCH IN BUSINESS AND SOCIAL SCIENCES

Vol. 11, No. 14, Contemporary Business and Humanities Landscape Towards Sustainability. 2021, E-ISSN: 2222-6990 @ 2021 HRMARS

between managers and shareholders because managers carry a lot of information that shareholders would not know.

\section{Conceptual Framework}

The dependent variable for this study is sustainability reporting disclosure (SRD). The independent variables are firms' size (FSZ), firms type (FTY) profitability (PRO), and achievements (ACH) as proxies to firms' characteristics. The control variable used in this study is internal goals (ING) of the company. Figure 1 summarises the relationship between these variables.

\section{Firms Size}

Based on past researchers, a company's size has a positive association with disclosure limits in the annual state government reports (Taylor and Rosair, 2000), disclosure of accountability (Ryan et. al, 2002), disclosure of accounts (Gore, 2004) and disclosure of the Internet (Groff and Pitman, 2004). Based on institutional theory, the mass media are more dense to investigate the large public sector because of the the coercive political pressure in the business (Falkman and Tagesson, 2008). Besides that, larger companies are hypothesized to institutionalize their practices and programs to maintain the social principles and expectations that contribute to the hypothesis that:

H1: Firms size has significant relationship towards sustainability reporting disclosure.

\section{Firms Type}

In Malaysia, there are eight markets. From the eight markets, the market been classified into two sectors which are manufacturing companies and non-manufacturing companies. Different industries have different characteristics and for each sector there is growth potential, jobs, competition, nature of its operations, market risk and government interference are different so the consistency of the reported information is compatible with the various types of industries (Gao. et al., 2005; Brammer and Pavelin, 2008). Companies with adverse environmental effects have more detail in the report relative to other companies (Reverte, 2009). Furthermore, when new manufacturing and service industries have less environmental effects, less information on environmental aspects would be released. Gamerschlag et al., (2010) points out that companies categorized as consumer and energy supply industries include more CSR information in disclosures compared to those in the service sector that disclose less details in the study leading to the following hypothesis:

H2: Firms type has significant relationship towards sustainability reporting disclosure.

\section{Profitability}

A profitable business has the freedom and versatility to show stakeholders its CSR activities, legitimizing and corporality (Khan, 2010). Based on the past research, Epps and Cereola (2008) claimed that the operating output of a business organisation can be calculated using Return on Asset (ROA) which shows the amount of earnings from the resources they own. Disclosure of the CSR is a synonym for SR. Therefore, researcher can refer to CSR's past research. Other past researchers, however, found that there is no association between profitability and CSR disclosure, because CSR initiatives add costs without direct benefits (Patten, 1991, da Silva Monteiro and Aibar-Guzman, 2010a, 2010b; Mohd Ghazali, 2007). The results relating to profitability to ethical behavior are mixed (Gozali et. al,2002). The economic performance of companies voluntarily sending sustainability 
reports is higher than those who do not follow sustainability reporting standards for Global Reporting Initiatives (GRIs) (Buys et.al, 2011). This mixed results from the past research leads to the following hypothesis:

H3: Profitability has significant relationship towards sustainability reporting disclosure.

\section{Achievements}

When an organization winning a recognizing award, the company will get the lawfulness. According to Meyer and Rowan (1977); DiMagio and Powel (1983), legitimate would guarantee long term viability and economic benefits for the company. Based on Coyle-Shapiro et al, (2004), the characteristic given in the annual reports competition as a coercive isomorphic pressure because the awards and recognitions of the company are subject to greater political visibility compared to those companies that have not received any awards. With the award-winning organization's increased political visibility that led to the following hypothesis:

H4: Achievements has significant relationship towards sustainability reporting disclosure.

\section{Independent Variables}

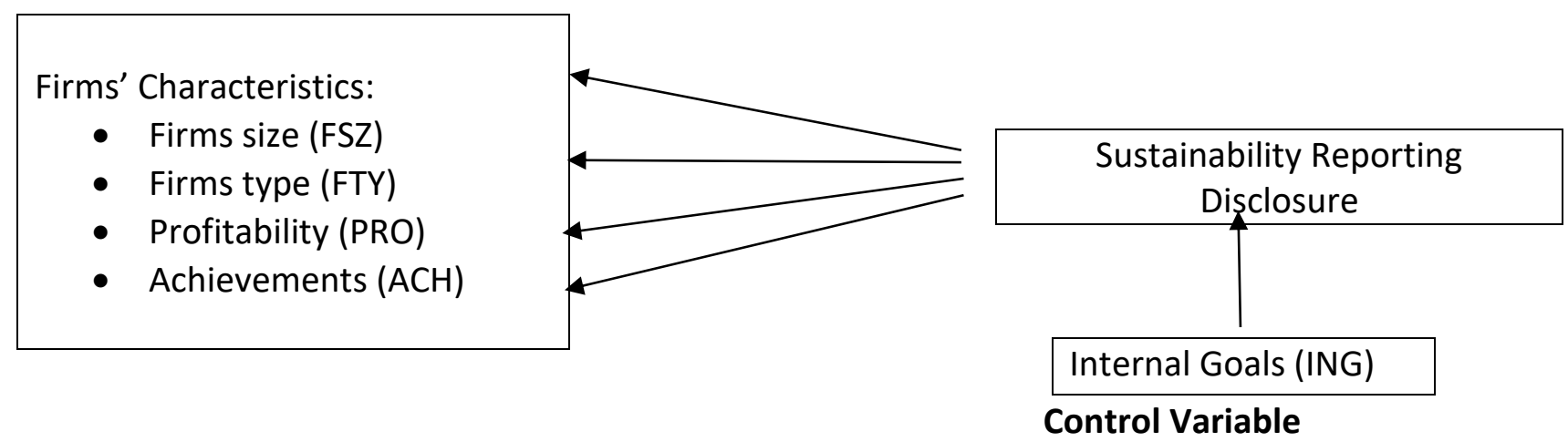

Figure 1: The relationship between Sustainability Reporting Disclosure and Firms' Charateristics

\section{Data Analysis}

\section{Sample Description and Data Collection}

The companies selected as samples for this research are based on the companies listed in the Main Board of Bursa Malaysia. Based on Bursa Malaysia, there are eight industries in the market, and it had been classified into two group which is manufacturing industry and non-manufacturing industry. The samples selected are companies that are involved in both industries which is manufacturing industry and non-manufacturing industry. For manufacturing companies are including industrial, petroleum, food and beverages while for non-manufacturing companies provide services such as consumer services. Such companies that have been selected are not in the financial sector as they are regulated by the Banking and Financial Institution Act for companies that have different requirements under the finance sector relative to other sectors. For the manufacturing companies, because they are involved in producing products. The products must be in high quality because to fulfill the customer requirements. Besides that, their business environment always provides greater disclosure in the annual report because they make it as a communication tool to the outside users 
such as investors and customers (Watson et al., 2002). In this research, the focus of estimation is sustainability reporting disclosure to measure the sustainability of the report. Sustainability report is measured the economic, social, environment and governance of the companies in the annual report. This study includes total observations of 180 companies which comprises of 60 annual reports for three years starting from year 2014 to 2016.

\section{Measurement of Variables}

The method of analysis of the data presented in this study is acceptable for the preferred tools of the Social Sciences Statistical Package (SPSS).

Sustainability Reporting Disclosure (Dependent Variable)

SRD is measured by ESG the disclosure score, which is the environmental disclosure score, the social disclosure score and the governmental disclosure score. There are a variety of different Socially Responsible Investment Indices, the same applies to sustainability indexes created to assess the sustainability of companies' requirements for social, economic, environmental, corporate governance and environmental (Escrig-Olmedo et. al, 2014; Sariannidis et. al, 2009) found that the most well-known Socially Responsible Investment (SRI) indices are lack of transparency, which is one of the challenges because essential information about the calculation mechanism is not published and the industry dimension created by the companies is ignored. Blomberg online database provided the ESG disclosure score in order to measure the extent of SRD.

$$
\begin{gathered}
\qquad R i=\Sigma X i / n i \\
\text { Where } \mathrm{ni}=\text { number of items expected for } \mathrm{i} \text { company, } \mathrm{ni} \leq 18 \\
\mathrm{Xi}=1 \text { if the item is disclosed, } 0 \text { if the item is not disclosed, } \\
\text { so that } 0 \leq \mathrm{SRi} \leq 1 .
\end{gathered}
$$

Firms Size (Independent Variable)

The size of the company can be measured according to the total amount of assets the circumstantial company has. The larger company conducted more activities compared to the smaller company. This contrast give impact to the society because more activities will lead to more investors and more customers attract to the company. The formula used to measure the size of the company is as follows:

$$
\text { Size }=\log 10 \text { (total assets) }
$$

\section{Firms Type (Independent Variable)}

The type of company can be measured by what type of industry that the company involved. Different industries can provide a different level of disclosure, based on Wallace et al (1994). That is due to each industry's specific characteristics. According to Abdul Rashid \& Ibrahim (2002); Amran \& Devi (2008); Saleh, et al (2010), the finance sector and the plantation sector were found to have the highest SR level, while the hotel sector was found to have the lowest SR level. (Saleh, et al, 2010). The category of industry can be found in the company's annual report.

\section{Profitability (Independent Variable)}

For profitability, it will be used to investigate whether it will give positive impact or negative impact to the SRD among public listed companies in Malaysia. The researcher used return on asset (ROA) in this study to measure the companies' profitability. Some of the past studies used ROA as their 
measurement such as Brick et al., (2006); Cheng, (2011); Jackling and Johl, (2009); Brown and Caylor, (2005); Klein, (1998). Return on assets (ROA) measures the return by using the assets to get income output. For the fiscal period divided by total assets for the same year, ROA was often referred to as net profit before interest expenses. This calculation shows the total earnings generated from the capital assets invested (Epps and Cereola, 2008). We used ROA to impose the operating performance of firms' relating to the investments made without knowing if the firm used debt or equity to make investments (Stickney, 1996). This measurement is a well-understood firm measurement (Kim, 2005), and described the actual company performance (Ponnu, 2008). This ratio calculated the relationship between the total profit before interest and tax and the total number of assets represented as a percentage. The equation can be draw as follows:

$$
R O A=\frac{\text { Net profit before interest and tax }}{\text { Total Assets }} \times 100
$$

\section{Achievements (Independent Variable)}

According to Meyer and Rowan (1977), to define the value of the structured elements, award criterion can be used as a ceremonial assessment. In year 2008, a star rating system had been designed. This system is developed to measure the performance of Malaysia's local companies. One evaluation criteria is based on the websites of the companies. In this study, researchers used binomial form which is dummy variable $(1,0)$. When the company reported their awards and recognitions in the report, score ' 1 ' will be denoted and otherwise, score ' 0 ' will be denoted.

\section{Internal Goals (Control Variable)}

Mohd-Ali et alz (2006) emphasize that the social, economic and environmental public interest will bring benefits to society. The justification for this is that public interest needs to be expressed in the mission statements of the businesses to demonstrate commitment to society. Internal goals are measure by the disclosure score which is score ' 1 ' was given to the companies that had mission statement and objectives related to SRD and ' 0 ' if otherwise (Amran and Devi's, 2007). Elijido-Ten (2004) also used the same measurement to measure the internal goals of the company. 
INTERNATIONAL JOURNAL OF ACADEMIC RESEARCH IN BUSINESS AND SOCIAL SCIENCES

Vol. 11, No. 14, Contemporary Business and Humanities Landscape Towards Sustainability. 2021, E-ISSN: 2222-6990 @ 2021 HRMARS

\section{Results}

Descriptive Statistic Analysis

Descriptive statistical analysis refers to a briefing of descriptive coefficients summarizing a given data set which can be either a representation or a sample of the entire population. From Table 1, the information shows the minimum, maximum, mean and standard deviation for independent variables and control variable to identify the research question's "how much" component in this study.

\begin{tabular}{|c|c|c|c|c|c|}
\hline Variables & Observations & Minimum & Maximum & Mean & Std. Dev. \\
\hline SRD & 60 & 0 & 1 & 0.6 & 0.491264 \\
FSZ & 60 & 4.700297 & 8.866303 & 6.288534 & 0.982591 \\
FTY & 60 & 0 & 1 & 0.566667 & 0.496918 \\
PRO & 60 & -17.28 & 314.39 & 19.71033 & 43.93665 \\
ACH & 60 & 0 & 1 & 0.505556 & 0.501364 \\
ING & 60 & 0 & 1 & 0.533333 & 0.500279 \\
\hline
\end{tabular}

Table 1: Descriptive Statistics Analysis

This study provided 60 companies listed on Bursa Malaysia as the research samples. The annual report and sustainability report from year 2014 until year 2016 were collected and analyzed. Table 1 displays descriptive statistical data used in the study, showing the minimum and maximum values, mean and standard deviations for all variables. SRD is measured by using disclosure index which is based on Economic, Environment, Social and Governance (EESG) context. Based on Table 1 analysis, it reveals that the total number of items reported to the sample companies between 2014 and 2016 is 0.6 (range 0 to 1 ) with the gap between the minimum and maximum value. The standard deviation figure is 0.491264 which is lower compare to the mean. This result indicates that over the mean value is clustered in more data. For the first variable, FSZ has the mean of 6.288534 (range from 4.700297 to 8.866303) of the companies that calculated using log 10 of the total assets of the companies, which means that the sample of the companies has an average of 6.288534 FSZ. The standard deviation also lies on 0.9825910 respectively. The standard deviation value is lower than the mean which means that more data is clustered around the mean value. The second variable, is the firms type (FTY), which is measured by the disclosure index 1 is for the manufacturing company while 0 is for the nonmanufacturing company. The descriptive analysis shows that the mean of FTY is 0.566667 (range from 0 to 1 ) while its standard deviation is 0.496918 . This implies the clustering of more data about the mean value. The third variable, the profitability of PRO with a mean of 19,71033 , is calculated by formula of return on equity (ROE) of the companies. Through this variable, it shows that the companies that have gained more profit is more sustainable. The range of the profitability with the lowest number of 17.28 and the highest number is 314.39. Its standard deviation is 43.93665 which higher than the mean value. This indicates that less of the data is clustered about the mean value. The fourth variable on company awards and awards defined by ACH has an average value of 0.505556 with a minimum value of 0 and a maximum value of 1 . ACH is measured by disclosure index which is 1 represented for have awards and recognitions and 0 for no awards and recognitions. The standard deviation of $\mathrm{ACH}$ (0.501364) is smaller than its mean (0.505556) which means that more of the data is clustered about the mean value. Lastly, Table 3 also indicates descriptive statistics for the control 
variable in this study which is internal goals of the company (ING). This variable is measured by represented 1 for have internal goal and 0 for company that do not have internal goal. Based on the table above, GOALS have mean of 0.533333 (range from 0 to 1) with the value of standard deviation is 0.500279 . This shows that more of the data is clustered about the mean value.

\section{Correlation Coefficient}

Table 2 summarizes the correlation between dependent variable and independent variables. It substantiates the size of company (FSZ), profitability (PRO) and achievements of company (ACH) are related to the disclosure index of sustainability report disclosure (SRD).

\begin{tabular}{|c|c|}
\hline Variables & SRD \\
\hline Firms Size (FSZ) & $0.380 * *$ \\
\hline Firms Type (FTY) & $-0.0275^{*}$ \\
\hline Profitability (PRO) & $0.206 * *$ \\
\hline Achievements $(\mathrm{ACH})$ & $0.553 * *$ \\
\hline Internal Goals (ING) & $0.555^{* *}$ \\
\hline
\end{tabular}

Table 2: Correlation coefficient between variables

Based on past researcher, Rebekic et al., (2015), $r>0$ is known as positive relationship while for $r<0$ is known as negative relationship and $r=0$ is known as no relationship. According to the table $2, \mathrm{ACH}$ is the strongest correlation among the independent variables while PRO is the weakest correlation. Based on the result, majority of the independent variables have significant positive correlations. This demonstrates from the above Table 2, that the scale of firms has a positive relationship with SRD with a positive $r$ value of 0.380 (Sig.=0.000). The companies that have high total assets are use SRD in their business operations. This FSZ is a weak positive linear relationship with SRD. Table 2 also shows that profitability has a positive SRD relationship, with a positive $r$ value of 0.206 . The companies that have high profitability are concerned to use the SRD in their business operations. This PRO is a weak positive linear relationship with SRD. From the above table, it shows that type of company has a no relationship with SRD with a negative $r$ value of -0.0275 and nearest to 0 . The companies that classified as neither manufacturing company nor non-manufacturing company is not concern in using SRD in their business operations. This FTY has no linear relationship with SRD because the value of the correlation is nearest with 0 . Besides that, PRO is the lowest positive correlation compared to other independent variables. Referring to the above Table 2, the company's award and recognition or achievements have a positive relationship with SRD with a positive $r$ value of 0.553 . The companies that received awards and recognition is more concern in using SRD in their business operations. These $\mathrm{ACH}$ have a moderate positive relationship with SRD because the value of correlation is nearest with 0.50 . ACH also represents the strongest correlation compared with other independent variables. Finally, the table above indicates that the company's internal goals have a positive relationship with SRD, with a positive $r$ value of 0.555 . The companies that have mission statement or internal goals for their business operations more concern to put it in the SRD. These 
ING have a moderate positive relationship with SRD because the value of correlation is nearest with 0.50. ING is the strongest correlation among the variables.

Regression Results

According to Table 3 below, it shows that the influence of companies' size (FSZ), profitability (PRO) and companies' achievements (ACH) have a value of $\mathrm{R}$ square of 0.363262 .

\begin{tabular}{|l|c|}
\hline \multicolumn{2}{|c|}{ Regression Statistics } \\
\hline Multiple R & 0.602711870 \\
\hline R Square & 0.3632261598 \\
\hline Adjusted R Square & 0.348707578 \\
\hline Standard Error & 0.396463646 \\
\hline Observations & 180 \\
\hline
\end{tabular}

Table 3: Regression Results

This indicates that the independent variables can explain the overall test has a $36.33 \%$ effect on the SRD. Another $63.67 \%$ can be explained by other variables do include in this equation. The Anova Statistics for regressions running with the independent variables in Figure 2 denoting the overall regression model are significant due to the recorded probabilities being less than the traditional $0.00 \%(0 \%)$ that is $2.303 \mathrm{E}-16<\mathrm{p}$-value. This results in a strong connection forecast of the dependent variable for all independent variables and control variable. According to the Anova, $F$ statistics is 24.96. Then, researcher found the line summarizes the residual which is the residual sum of squares is 27.507 with a degree of freedom of 175 . This amount resulting in a mean squared error which is 0.157 . Next is the model added with the residual sum square and equal the total sum of square weight after the removal of the mean which is similar with model add the residual degree of freedom to the total degree of freedom of 179. There are 180 observations then minus 1 observation for mean resulting total degree of freedom become 179.

\begin{tabular}{|c|c|c|c|c|c|}
\hline \multicolumn{6}{|l|}{ ANOVA } \\
\hline & Df & SS & MS & $\mathbf{F}$ & Significance F \\
\hline Regression & 4 & 15.69290105 & 3.923225264 & 24.95953581 & $2.30288 \mathrm{E}-16$ \\
\hline Residual & 175 & 27.50709895 & & & \\
\hline Total & & 179 & 43.2 & & \\
\hline
\end{tabular}

Figure 2: ANOVA Statistics

\section{Multiple Regression Analysis}

The regression analysis in Table 4 below indicates that among the four independent variables, $\mathrm{ACH}$ have the highest Beta value which is 0.335 which indicates that it has the greater influence towards 
relationship of SRD. Besides that, FSZ have the Beta value of 0.045. PRO has 0.002 of Beta value which shows that it has the lowest of Beta value compared to other independent variables. It means that profitability is not the most influential variable in explaining the dependent variable, SRD. For the significant values, all the independent variables are less than 0.05 . It shows that all the variables have significant contribution as predictors for the SR.

\begin{tabular}{|c|c|c|}
\hline Independent Variables & Beta $(\boldsymbol{\beta})$ & Significant Value \\
\hline Firms Size (FSZ) & 0.045 & 0.05 \\
\hline Firms Type (FTY) & 0.153 & 0.00 \\
\hline Profitability (PRO) & 0.002 & 0.01 \\
\hline Achievements (ACH) & 0.335 & 0.00 \\
\hline Internal Goals (ING) & 0.289 & 0.00 \\
\hline
\end{tabular}

\section{Discussion}

Table 4: Regression analysis of SRD

The evidence indicate in the above indicates four key firms characteristics i.e. firms size, firms type, profitability and achievements have significant impact towards sustainability reporting disclosure. Most of the prediction made about the independent variables that influence the SR are positive except firms type which has negative value. Hence, this study concluded that among the four variables, achievements that consists of awards and recognitions received by the company have the strongest influence towards sustainability reporting disclosure in response to the economic, social and environmental performance. Winning a business award gives the company a reliable endorsement from relevant stakeholders that they honour their business relationship which inevitably improve brand awareness and generate more sales. Winning a social impact award is a perfect opportunity for the company to showcase its corporate social responsibility credentials as it sets a clear evidence of the company's impact in a highly competitive industry and not just ambiguous policy statements on the paper. Depending on how prestigious the award is, it opens doors to new business and increases the level of SRD. This is followed by firms type. It indicates that type of company and the SRD have a negative relationship which is the type of company does not affect the influence of SRD index. For example, most of manufacturing companies did not used SRD for their business operation because SR is new implemented in Malaysia. Next, the firms size signifies that as a company grows from middle-sized to large company, level of sustainable reporting disclosure increases to account for the environmental and social aspects. Profitability, ranked at the bottom four after achievements and firms size, indicates that highly profitable companies use the sustainability reporting disclosure to report on the environmental and social effects of their everyday operations. Hence, companies do not focus solely on profitability to meet the needs of their stakeholders, particularly shareholders. Instead, they sustain their relationships by extending their commitment towards broader sustainability reporting disclosure on economic, social and environmental issues. A growing number of investors indicates that they prefer to invest in transparent organisations as there is high confidence between managers and stakeholders, more reliable prediction, and low information imbalance (Jiang and $\mathrm{Fu}, 2019)$. Hence, the overarching theory in the whole framework of this study is relevant to stakeholder theory where SR serves the means of contact between companies and their stakeholders on the various economic, social and 
environmental aspects (Jiang and Fu, 2019; Vijayakumaran, 2019; Bae et. al, 2018; Masud et. al, 2018; Yusoof et al., 2016). In a nutshell, companies can increase transparency to provide benefits through revealing economic, social and environmental performance to their stakeholders such as investors, workers, consumers, suppliers, creditors and other stakeholders through sustainability reporting.

\section{Conclusion}

The main purpose of this study is to study the influence of four independent variables namely firms size (FSZ), firms type (FTY), profitability (PRO) and achievements (ACH) towards sustainability reporting disclosure (SRD). The control variable, internal goals is also examined to find the relationship with SRD. Overall, the results from this study indicates that firms characteristics such as company performance, type, size and profitability influence the degree of sustainability reporting disclosure. The results and findings from this study will educate investors on how the management handles their non-financial reporting which consists of economics, environment, social and governance. Besides that, investors should pick up the concept of how SR transparency eliminates information asymmetry issues. On the other perspective, this study allows managers to achieve a more strategic advantage from non-financial activities. Managers will learn from this study how to boost the impetus for SR disclosure in the annual report. For example, the manager can use a list to evaluate the SR activities of their companies and to subsume the corporate governance, environment, economic, social, award and recognitions received and the internal goals of the companies.

There are several limitations related to this study. The disclosure index is the measurement of the disclosure score for this research which is gained by reading and illuminating the content of companies' annual reports. This resulted to the limited research by its pillar on the researcher's subjective clarification of the content of companies' annual reports. Secondly, this study had limited data collection due to SR is still new in Malaysia. In fact, SR is not compulsory for the company to report in the annual report. Most of the listed companies choose to do other non-financial reports such as CSR (CSR) and three bottom line report. Therefore, for the data collection, this study is based on CSR disclosure index as the data collection for the results and findings related to the independent variables and control variable. Basically, the contents of SR and CSR are similar, but the difference is the term used in the report. As example, for the SR, the term used EESG context which are economic, environment, social and governance while for CSR, it used marketplace and social. Lastly, the number of sample is limited because there is lack of information that can be acquired. A few companies have insufficient data and information excerpted from the annual reports and internet resource are not in specific. There are several companies that newly enter the industry has inexpert to accomplish the non-financial reporting coupled with the newly introduced, SR, by Bursa Malaysia. The limitations of this study have subjected to the necessity for further research. For the future research, the researcher shall engage more sample size. Besides that, the period of the observations must be longer to reduce the limitation of data collection. This recommendation can help the researcher to gain more understanding and rigid results to interpret the influence of sustainable reporting disclosure and the characteristics of the company to develop sustainable reporting in their business management. Furthermore, a sizeable number of samples would help to ease well-conditioned check among the variables of the sustainable reporting. This study used sustainable reporting disclosure index which 
is constructed by Escrig-Olmedo et al., (2010) as the representative SR disclosure in the annual reports. There are several other representatives that the potential researcher can use as the information for disclosure in the annual report to analyze the relationship between independent variables and sustainable reporting. Some researcher used information quality and board independence. The relationship of other representatives can supply potential interest to other users such as the investors, managers and researchers of Malaysian companies. Future research also can use the Global Reporting Initiative (GRI) for the sustainable reporting as the measurement or guideline for the researcher in their research since Bursa Malaysia also provide the sustainable reporting guideline to the listed companies in Malaysia to guide the companies to develop the sustainable reporting in their companies.

\section{References}

Abdul, Z., \& Ibrahim, S. (2002). Executive and management attitudes towards corporate social responsibility in Malaysia. Corporate Governance: The international journal of business in society, 2(4), 10-16. https://doi.org/10.1108/14720700210447641

Adams, C. A., \& Frost, G. R. (2006). Accessibility and functionality of the corporate web site: Implications for sustainability reporting. Business Strategy and the Environment, 15(4), 275287. https://doi.org/10.1002/bse.531

Ali, M., \& Azizi, N. (2006). Putrajaya and The French Connection, Faculty of Architecture and Planning [Paper presentation]. Universiti Teknologi Malaysia, Kuala Lumpur.

Amran, A., \& Susela Devi, S. (2008). The impact of government and foreign affiliate influence on corporate social reporting. Managerial Auditing Journal, 23(4), 386-404. https://doi.org/10.1108/02686900810864327

Bae, S., Masud, M., \& Kim, J. (2018). A cross-country investigation of corporate governance and corporate sustainability disclosure: A signaling theory perspective. Sustainability, 10(8), 2611. https://doi.org/10.3390/su10082611

Baden, D., \& Harwood, I. A. (2012). Terminology matters: A critical exploration of corporate social responsibility terms. Journal of Business Ethics, 116(3), 615-627. https://doi.org/10.1007/s10551-012-1498-9

Baker, R., \& Rennie, M. D. (2006). Forces leading to the adoption of accrual accounting by the Canadian federal government: An institutional perspective. Canadian Accounting Perspectives, 5(1), 83-112. https://doi.org/10.1506/206k-rv7l-2jmn-w3d3

Barrett, M.E. (1976). Financial reporting practices: Disclosure and comprehensiveness in an international setting. Journal of Accounting Research, 14(1), 10. https://doi.org/10.2307/2490455

Bebbington, J., O' Dwyer, B., \& Unerman, J. (2007). Postscript and conclusions. Sustainability Accounting and Accountability, 345-349. https://doi.org/10.4324/noe0415384889.ch18

Boatright, J. R. (2003). Ethics and the conduct of business (4th ed.). Prentice Hall, Englewood Cliff.

Brammer, S., \& Pavelin, S. (2008). Factors influencing the quality of corporate environmental disclosure. Business Strategy and the Environment, 17(2), 120-136.

https://doi.org/10.1002/bse.506

Brick, I. E., Palmon, O., \& Wald, J. K. (2006). CEO compensation, director compensation, and firm performance: Evidence of cronyism? Journal of Corporate Finance, 12(3), 403-423. 
INTERNATIONAL JOURNAL OF ACADEMIC RESEARCH IN BUSINESS AND SOCIAL SCIENCES

Vol. 11, No. 14, Contemporary Business and Humanities Landscape Towards Sustainability. 2021, E-ISSN: 2222-6990 @ 2021 HRMARS

https://doi.org/10.1016/j.jcorpfin.2005.08.005

Brignall, S., \& Modell, S. (2000). An institutional perspective on performance measurement and management in the 'new public sector'. Management Accounting Research, 11(3), 281306. https://doi.org/10.1006/mare.2000.0136

Brown, L. D., \& Caylor, M. L. (2005). A temporal analysis of quarterly earnings thresholds: Propensities and valuation consequences. The Accounting Review, 80(2), 423-440. https://doi.org/10.2308/accr.2005.80.2.423

Buhr, N. (2007). Histories of and rationales for sustainability reporting. Sustainability Accounting and Accountability, 57-69. https://doi.org/10.4324/noe0415384889.pt2

Buys, P., Oberholzer, M., \& Andrikopoulos, P. (2011). An investigation of the economic performance of sustainability reporting companies versus non-reporting companies: A South African perspective. Journal of Social Sciences, 29(2), 151-158. https://doi.org/10.1080/09718923.2011.11892965

Cheng, B., loannou, I., \& Serafeim, G. (2013). Corporate social responsibility and access to finance. Strategic Management Journal, 35(1), 1-23. https://doi.org/10.1002/smj.2131

Coyle-Shapiro, J. A., Kessler, I., \& Purcell, J. (2004). Exploring organizationally directed citizenship behaviour: Reciprocity or 'It's my job'?. Journal of Management Studies, 41(1), 85106. https://doi.org/10.1111/j.1467-6486.2004.00422.x

Crossman, K. M. (2013). The roles of non-governmental organizations in marine conservation [Doctoral dissertation.

Da Silva Monteiro, S. M., \& Aibar-Guzmán, B. (2010a). Determinants of environmental disclosure in the annual reports of large companies operating in Portugal. Corporate Social Responsibility and Environmental Management, 17(4), 185-204. https://doi.org/10.1002/csr.197

Da Silva Monteiro, S. M., \& Aibar Guzmán, B. (2010b). The influence of the Portuguese environmental accounting standard on the environmental disclosures in the annual reports of large companies operating in Portugal. Management of Environmental Quality: An International Journal, 21(4), 414-435. https://doi.org/10.1108/14777831011049070

Deegan, C. (2013). The accountant will have a central role in saving the planet ... really? A reflection on 'green accounting and green eyeshades twenty years later'. Critical Perspectives on Accounting, 24(6), 448-458. https://doi.org/10.1016/j.cpa.2013.04.004

Deegan, C. (2013). Financial accounting theory (2nd ed.). McGraw-Hill Higher Education London.

Deegan, C., \& Blomquist, C. (2006). Stakeholder influence on corporate reporting: An exploration of the interaction between WWF-Australia and the Australian minerals industry. Accounting, Organizations and Society, 31(4-5), 343-372. https://doi.org/10.1016/j.aos.2005.04.001

Deegan, C., Rankin, M., \& Tobin, J. (2002). An examination of the corporate social and environmental disclosures of BHP from 1983-1997. Accounting, Auditing \& Accountability Journal, 15(3), 312-343. https://doi.org/10.1108/09513570210435861

DiMaggio, P. J., \& Powell, W. W. (1983). The iron cage revisited: Institutional isomorphism and collective rationality in organizational fields. American Sociological Review, 48(2), 147160. https://doi.org/10.2307/2095101

Epps, R. W., \& Cereola, S. J. (2008). Do institutional shareholder services (ISS) corporate governance ratings reflect a company's operating performance? Critical Perspectives on Accounting, 19(8), 1135-1148. https://doi.org/10.1016/j.cpa.2007.06.007 
Escrig-Olmedo, E., Muñoz-Torres, M. J., Fernández-Izquierdo, M. A., \& Rivera-Lirio, J. M. (2014). Lights and shadows on sustainability rating scoring. Review of Managerial Science, 8(4), 559574. https://doi.org/10.1007/s11846-013-0118-0

Freeman, R. E. (1984). Strategic management: A stakeholder approach. Boston: Pitman.

Freeman, R. E. (2010). Strategic management: A stakeholder approach. Cambridge University Press.

Freeman, R. E., Wicks, A. C., \& Parmar, B. P. (2004). Stakeholder theory and the corporate objective revisited. Organization Science, 15(3), 364-369.

Gamerschlag, R., Möller, K., \& Verbeeten, F. (2011). Determinants of voluntary CSR disclosure: Empirical evidence from Germany. Review of Managerial Science,5(2-3), 233262. https://doi.org/10.1007/s11846-010-0052-3

Gao, S. S., Heravi, S., \& Xiao, J.Z. (2005). Determinants of corporate social and environmental reporting in Hong Kong: A research note. Accounting Forum, 29(2), 233-242. https://doi.org/10.1016/j.accfor.2005.01.002

Gozali, N. O., How, J. C. Y., \& Verhoeven, P. (2002). The economic consequences of voluntary environmental information disclosure. http://www.iemss.org, 31.08.2012

Graves, S. P., Waddock, S., \& Kelly, M. (2001). How do you measure corporate citizenship? Business Ethics, 12(2), 155-187.

Haniffa, R., \& Cooke, T. (2005). The impact of culture and governance on corporate social reporting. Journal of Accounting and Public Policy, 24(5), 391430. https://doi.org/10.1016/j.jaccpubpol.2005.06.001

Hategan, C., Sirghi, N., Curea-Pitorac, R., \& Hategan, V. (2018). Doing well or doing good: The relationship between corporate social responsibility and profit in Romanian companies. Sustainability, 10(4), 1041. https://doi.org/10.3390/su10041041

Heinze, D. C. (1976). Financial correlates of a social involvement measure. Akron Business and Economic Review, 7(1), 48-51.

Hezri, A. A., \& Hasan, N. M. (2006). Towards sustainable development? The evolution of environmental policy in Malaysia. Natural Resources Forum, 30(1), 3750. https://doi.org/10.1111/j.1477-8947.2006.00156.x

Izzo, M. F., Ciaburri, M., \& Tiscini, R. (2020). The challenge of sustainable development goal reporting: The first evidence from Italian listed companies. Sustainability, 12(8), 3494. https://doi.org/10.3390/su12083494

Jackling, B., \& Johl, S. (2009). Board structure and firm performance: Evidence from India's top companies. Corporate Governance: An International Review, 17(4), 492505. https://doi.org/10.1111/j.1467-8683.2009.00760.x

Jensen, M. C., \& Meckling, W. H. (1976). Theory of the firm: Managerial behavior, agency costs, and ownership structure. In K. Brunner (Ed.), Economics social institutions. Rochester studies in economics and policy issues, vol. 1 (pp. 163-231). Springer, Dordrecht.

Jiang, C., \& Fu, Q. (2019). A win-win outcome between corporate environmental performance and corporate value: From the perspective of stakeholders. Sustainability, 11(3), 921. https://doi.org/10.3390/su11030921

Jose, A., \& Lee, S. (2007). Environmental reporting of global corporations: A content analysis based on website disclosures. Journal of Business Ethics, 72(4), 307321. https://doi.org/10.1007/s10551-006-9172-8 
Joseph, C. (2013). Understanding sustainable development concept in Malaysia. Social Responsibility Journal, 9(3), 441-453. https://doi.org/10.1108/srj-03-2012-0024

Khan, H. (2010). The effect of corporate governance elements on corporate social responsibility (CSR) reporting. International Journal of Law and Management, 52(2), 82109. https://doi.org/10.1108/17542431011029406

Kim, Y. (2005). Board network characteristics and firm performance in Korea. Corporate Governance: An International Review, 13(6), 800-808. https://doi.org/10.1111/j.1467-8683.2005.00471.x

Klein, A. (1998). Firm performance and board committee structure. The Journal of Law and Economics, 16, 275-303. https://doi.org/10.1086/467391

Kolk, A. (2005). Sustainability Reporting. VBA Journal, 21(3), 34-42.

Lapsley, I., \& Pallot, J. (2000). Accounting, management and organizational change: A comparative study of local government. Management Accounting Research,11(2), 213229. https://doi.org/10.1006/mare.2000.0129

Maignan, I., \& Ralston, D. A. (2002). Corporate social responsibility in Europe and the U.S.: Insights from businesses' self-presentations. Journal of International Business Studies, 33(3), 497514. https://doi.org/10.1057/palgrave.jibs.8491028

Meyer, J. W., \& Rowan, B. (1977). Institutionalized organizations: Formal structure as myth and ceremony. American Journal of Sociology, 83(2), 340-363. https://doi.org/10.1086/226550

Munteanu, I., Grigorescu, A., Condrea, E., \& Pelinescu, E. (2020). Convergent insights for sustainable development and ethical cohesion: An empirical study on corporate governance in Romanian public entities. Sustainability, 12(7), 2990. https://doi.org/10.3390/su12072990

Modell, S. (2001). Performance measurement and institutional processes: A study of managerial responses to public sector reform. Management Accounting Research, 12(4), 437464. https://doi.org/10.1006/mare.2001.0164

Modell, S. (2005). Students as consumers? An institutional field-level analysis of the construction of performance measurement practices. Accounting, Auditing 62' Accountability Journal, 18(4), 537-563.

Ghazali, M. N. A. (2007). Ownership structure and corporate social responsibility disclosure: Some Malaysian evidence. Corporate Governance: The International Journal of Business in Society, 7(3), 251-266. https://doi.org/10.1108/14720700710756535

Nichol, E., \& Taylor, D. W. (2001). Accountability and performance reporting in the public accounts of the Malaysian government. The Journal of Contemporary Issues in Business and Government, 7(2), 35-46.

Our common future: Report of the world commission on environment and development. (1987). The Bruntland Report. http://www.worldinbalance.net/pdf/1987-brundtland.pdf

O'Donovan, G. (2002). Environmental disclosures in the annual report. Accounting, Auditing \& Accountability Journal, 15(3), 344-371. https://doi.org/10.1108/09513570210435870

Patten, D. M. (1991). Exposure, legitimacy, and social disclosure. Journal of Accounting and Public Policy, 10(4), 297-308. https://doi.org/10.1016/0278-4254(91)90003-3

Ponnu, C. H. (2008). Corporate governance structures and the performance of Malaysian public listed companies. International Review of Business Research Papers, 4(2), 217-230. 
Poolthong, Y., \& Mandhachitara, R. (2009). Customer expectations of CSR, perceived service quality and brand effect in Thai retail banking. International Journal of Bank Marketing, 27(6), 408427. https://doi.org/10.1108/02652320910988302

Rahaman, A. S., Lawrence, S., \& Roper, J. (2004). Social and environmental reporting at the VRA: Institutionalised legitimacy or legitimation crisis? Critical Perspectives on Accounting, 15(1), 35-56. https://doi.org/10.1016/s1045-2354(03)00005-4

Rebekic, A., Loncaric, Z., Petrovic, S., \& Maric, S. (2015). Pearson's or Spearman's correlation coefficient - Which one to use? Poljoprivreda, 21(2), 47-54. https://doi.org/10.18047/poljo.21.2.8

Reverte, C. (2009). Determinants of corporate social responsibility disclosure ratings by Spanish listed firms. Journal of Business Ethics, 88(2), 351-366.

Roberts, R. W. (1992). Determinants of corporate social responsibility disclosure: An application of stakeholder theory. Accounting, Organizations and Society, 17(6), 595612. https://doi.org/10.1016/0361-3682(92)90015-k

Saleh, M., Zulkifli, N., \& Muhamad, R. (2010). Corporate social responsibility disclosure and its relation on institutional ownership. Managerial Auditing Journal, 25(6), 591613. https://doi.org/10.1108/02686901011054881

Sariannidis, N., Litinas, N., Konteos, G., \& Giannarakis, G. (2009). A GARCH examination of macroeconomic effects on U.S. stock market: A distinguish between the total market index and the sustainability index. SSRN Electronic Journal. https://doi.org/10.2139/ssrn.1340574

Schaltegger, S., Bennet, M., \& Burritt, R. L. (2006). Sustainability accounting and reporting: Development, linkages and reflection. An introduction. In Sustainability Accounting and Reporting (pp. 1-33). Springer, Dordrecht.

Selznick, P. (1957). Leadership in administration. Harper \& Row, New York.

Stickney, C. P. (1996). Financial reporting and statement analysis: A strategic perspective. Fort Worth, TX: Dryden Press.

Suchman, M. C. (1995). Managing legitimacy: Strategic and institutional approaches. Academy of Management Review, 20(3), 571-610. https://doi.org/10.5465/amr.1995.9508080331

Taylor, D. W., \& Rosair, M. (2000). The effects of participating parties, the public, and size on government departments' accountability disclosures in annual reports. Accounting, Accountability and Performance, 6(1), 77-97.

Thornton, P. H., \& Ocasio, W. (2008). Institutional Logics. In R. Greenword, C. Oliver, R. Suddaby, \& K. Sahlin (Eds.), The Sage Handbook of Organizational Institutionalism (pp. 1-46). Los Angeles: Sage Publications.

Tilt, C. A. (2001). Environmental Disclosure by Australian Companies: What is Happening Outside the Annual Report? Flinders University, Adelaide, South Australia.

Tsamenyi, M., Enninful-Adu, E., \& Onumah, J. (2007). Disclosure and corporate governance in developing countries: Evidence from Ghana. Managerial Auditing Journal, 22(3), 319334. https://doi.org/10.1108/02686900710733170

Vijayakumaran, R. (2019). Agency costs, ownership, and internal governance mechanisms: Evidence from Chinese listed companies. Asian Economic and Financial Review, 9(1), 133-154. https://doi.org/10.18488/journal.aefr.2019.91.133.154 
Wallace, R. S., \& Naser, K. (1995). Firm-specific determinants of the comprehensiveness of mandatory disclosure in the corporate annual reports of firms listed on the stock exchange of Hong Kong. Journal of Accounting and Public Policy, 14(4), 311368. https://doi.org/10.1016/0278-4254(95)00042-9

Watson, R., Stimpson, A., Topping, A., \& Porock, D. (2002). Clinical competence assessment in nursing:a systematic review of the literature. Journal of Advanced Nursing, 39(5), 421-431.

Yusoof, S., Iylia, F. Z., MNSR, H., Zamziba, N., \& Toriry, S. (2016). Relationship Between Economic, Political and Technology Factors: Case Study on Toyota Company. International Journal of Academic Research in Public Policy and Governace, 3(1), 53-58.

Zahid, M., Ghazali, Z., \& Rehman, H. (2016). Corporate sustainability practices \& reporting: A case of Malaysian REITs and property listed companies. International Journal of Economics and Financial Issues, 6(2).

Zeghal, D., \& Ahmed, S. A. (1990). Comparison of social responsibility information disclosure media used by Canadian firms. Accounting, Auditing \& Accountability Journal, 3(1), 3853. https://doi.org/10.1108/09513579010136343 